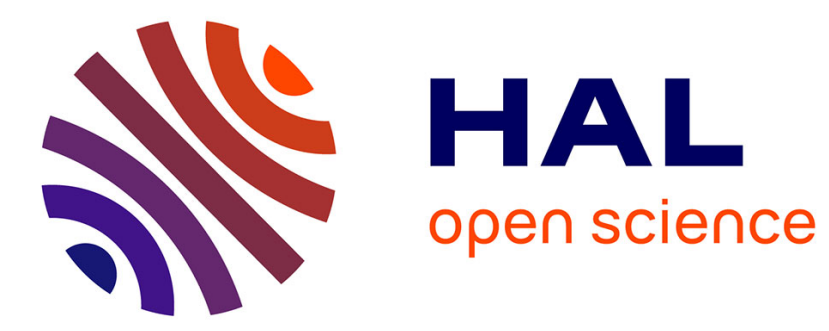

\title{
Results of French apricot rootstock trials
}

\author{
Henri Duval, Martin Masse, Michel Jay, Jean Lichou
}

\section{To cite this version:}

Henri Duval, Martin Masse, Michel Jay, Jean Lichou. Results of French apricot rootstock trials. 15. International Symposium on Apricot Breeding and Culture, Jun 2011, Yerevan, Armenia. hal02746087

\section{HAL Id: hal-02746087 \\ https://hal.inrae.fr/hal-02746087}

Submitted on 3 Jun 2020

HAL is a multi-disciplinary open access archive for the deposit and dissemination of scientific research documents, whether they are published or not. The documents may come from teaching and research institutions in France or abroad, or from public or private research centers.
L'archive ouverte pluridisciplinaire HAL, est destinée au dépôt et à la diffusion de documents scientifiques de niveau recherche, publiés ou non, émanant des établissements d'enseignement et de recherche français ou étrangers, des laboratoires publics ou privés. 


\section{ЈU도 \\ XV International \\ Symposium \\ $20-24$ \\ on Apricot Breeding \\ and Culture}

PISHS

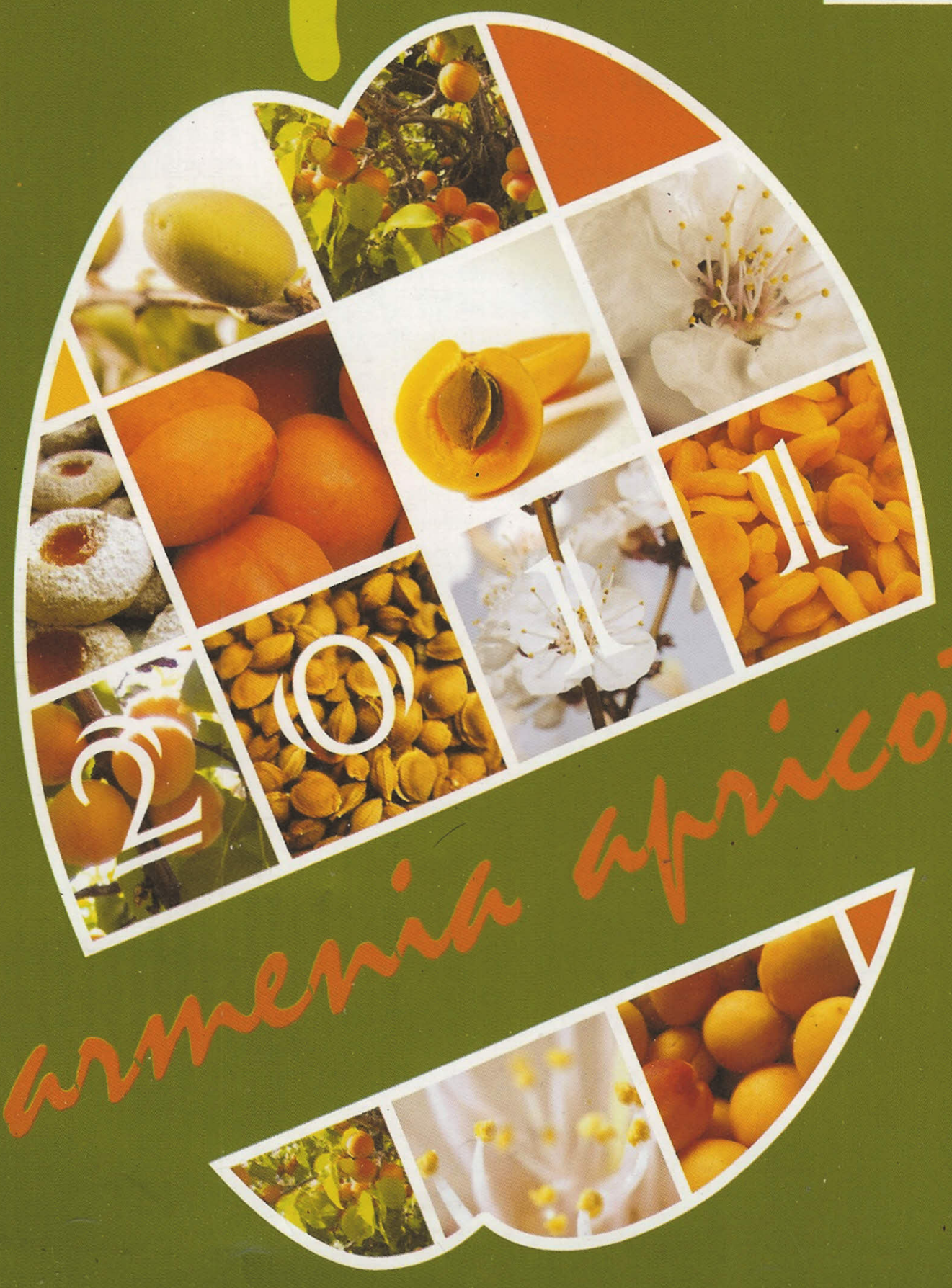




\title{
RESULTS OF FRENCH APRICOT ROOTSTOCK TRIALS
}

\author{
Henri Duval ${ }^{1}$, Martin Masse ${ }^{1}$, Michel Jay ${ }^{2}$, Jean Lichou ${ }^{2}$ \\ ${ }^{1}$ INRA GAFL Avignon, domaine de St Maurice, BP94, 84143 Montfavet, France \\ ${ }^{2}$ CTIFL, 751 chemin de Balandran, 30127 Bellegarde, France
}

In France, apricot trees are mainly grown on peach seedlings (Montclar $($ Chanturge, GF305, and Rubira) and apricot seedlings (Manicot GF1236) in the light soils, and rather on the clonal plum hybrid rootstock Torinel $₫ A$ ivifel, on myrobalan seedlings or clonal myrobalan rootstock (P1254) in heavy clay soils. The objectives of the apricot "rootstock breeding program of the INRA Avignon are to develop new rootstocks more vigorous than Torinel囚Avifel in heavy soils and more tolerant to bacterial canker and to

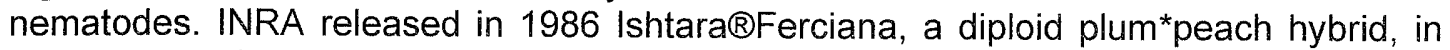
1989 Torinel囚Avifel a Prunus domestica hybrid and this year two new clonal rootstocks, Myrotop $® G F 2980$ (Prunus cerasifera) and Toriplus $® M P 8$ (Prunus domestica) are proposed to be released. The results of the behavior of these rootstocks in the French apricot rootstocks trials coordinated by the CTIFL, in the INRA orchards are presented. In the two apricot CTIFL trials, one planted in 1994 and the other planted in 2007, Ishtara®Ferciana gave a better cumulated yield than Torinel囚Avifel. In the INRA orchards and the 2007 CTIFL orchard, Myrotop®GF2980 showed a higher vigor than Ishtara $®$, Toriplus $®$, Torinel $\circledast$, and a lower susceptibility to the bacterial canker.

New INRA genotypes have been preselected to be introduced in the CTIFL trials in the next year. These new selected clonal rootstocks are peach*plum hybrids resistant to nematodes and bacterial canker, peach*davidiana hybrids very vigorous, almond*peach*plum hybrids with high vigor and resistance to nematodes.

Corresponding author: Henri Duval, Email: henri.duval@avignon.inra.fr 